Article

\title{
The Relationship of Vulnerability to Religiosity in the Adult Jewish Learner
}

\author{
Erica Brown 1,2 \\ 1 Department of Curriculum and Pedagogy, Graduate School of Education and Human Development, \\ The George Washington University, Washington, DC 20052, USA; ericabrown@gwu.edu \\ 2 Mayberg Center for Jewish Education and Leadership, The George Washington University, Washington, \\ DC 20052, USA
}

Received: 22 February 2019; Accepted: 29 April 2019; Published: 7 May 2019

check for updates

\begin{abstract}
This article examines the role of vulnerability in personal religious transformation. It offers several "working" definitions of the terms and also mines the use of the term through the portrait of three adult Jewish learners who each experienced vulnerability as a result of Jewish text study for different reasons. This sense of vulnerability was either itself a religious experience characterized as a mixture of humility, gratitude, and belonging or catalyzed enhanced study that led to a greater sense of knowledge of and participation within a religious community. Vulnerability is understood by one learner as the insecurity of ignorance, which inspired her to take agency for her learning and compensate for pre-existing gaps. For the second, vulnerability is less about ignorance or openness in an act of study, but the insecurity of the performative aspects of Judaism in the shared space of community. This prompted him to learn more to overcome these uncomfortable feelings. For another, vulnerability represents an existential state of humanity that connects all people. Vulnerability for her is a positive state of openness; she seeks out Jewish experiences of study and prayer where she can exhibit her vulnerability in the presence of others equally willing to share their own moments of joy, doubt, humility, and failure. In each instance, vulnerability created a paradoxical motivation to study - the discomfort of not fitting in or knowing enough that, in turn, gave rise to feelings of enhanced religiosity induced by the study experience. To that end, the paper also explores vulnerability as a generative aspect of transformative learning that leads to enhanced spiritual states.
\end{abstract}

Keywords: adult learner; vulnerability; religiosity; spirituality; faith; study; insecurity; transformative learning

In the traditional Siddur (Jewish prayerbook) immediately after the silent prayer (the Amida) and its requests for atonement, health, and prosperity, Jews in prayer fall on their right arms and recite a tender entreaty (Takhanun). The straight and sturdy petitioner suddenly turns into a meek and vulnerable supplicant: "Be gracious to me, Lord, for I am weak. Heal me, Lord, for my bones are in agony. My soul is in anguish ... I am weary with sighing. Every night, I drench my bed, I soak my couch with tears ..." (Sacks 2009, p. 152). Jewish prayer is an invitation into a range of emotions, balancing moments of human strength with humility before God. Vulnerability, as demonstrated in this daily prayer act, is an essential expression of the homo religiosus. The hunched body in a posture of weakness, unafraid to need God desperately, reaches out across the chasm, admits to being wounded, and cries out for healing. If achieving this equipoise is a desideratum in prayer, is it also a goal of Jewish study? And if so, how can a teacher facilitate such moments in the adult classroom? To answer the first question in the affirmative, this article presents three profiles of adult learners, each from different denominations and each with a different understanding of vulnerability. For one, vulnerability is about the insecurity and ignorance that catalyzed study. For another, vulnerability is connected to shame or embarrassment in the presence of community. For the third, vulnerability is an actual objective of 
study, a spiritual end unto itself. In each instance, vulnerability is vital and indispensable to Jewish study and makes the act of learning distinctively religious.

\section{Defining Vulnerability}

Vulnerability has been defined as the capacity for woundedness or the susceptibility to receive wounds. Much as the prayer that opened this article, vulnerability captures the deeply religious sense of smallness or brokenness from which a relationship to God might be crafted. The psalmist captures this sense of vulnerability: "The Lord is near to the brokenhearted and saves the crushed in spirit" [Psalms 34:18]. The supplicant describes his condition: "I have become like a broken vessel" [Psalms 31:12]. God is interested most, says Isaiah, in those who are broken vessels: " . . this is the one to whom I will look: He who is humble and contrite in spirit and trembles at my word." Isaiah describes God's task in the world as "reviving the spirit of the weak and visiting the heart of the contrite" [Isaiah 57:15].

Vulnerability can also refer directly to physical or emotional injury. Here, too, the psalmist resonates: God "heals the brokenhearted and binds up their wounds" [Psalms 147:3]. For a group, rather than as an individual, vulnerability means the state of being open to attack or assault by armed forces (Little et al. 1973, p. 2494). Vulnerability implies a state of exposure. The philosophers, Catriona Mackenzie, Wendy Rogers, and Susan Dodds, describe three different sources of and two different states of vulnerability. The first state is the capacity to suffer and to be susceptible to suffering as an ontological condition of humanity. Vulnerability is also, they argue, "fundamentally social or relational" since it describes particular groups of persons who may be under harm or threat because of their nature or condition. Thus, vulnerability, they contend, can be inherent, situational, or pathogenic, when referring to medical susceptibility (Mackenzie et al. 2014, pp. 4-7).

In contrast, the legal theorist and political philosopher, Martha Albertson Fineman, regards vulnerability as a tool that can potentially create self-understanding and greater compassion towards others. It emerges from the fact that we are born defenseless and, even when we acquire the means of self-protection, we are often foisted into situations beyond our control: "Vulnerability ... can be thought of as a heuristic device, forcing us to examine hidden assumptions and biases folded into legal, social, and cultural practices. Vulnerability is universal ... A second integral feature of vulnerability is its constancy" (Fineman 2013, p. 20). For Fineman, vulnerability is inevitable because it is connected to our physical condition, and this condition inevitability leads to death.

"Human vulnerability arises in the first place from our embodiment, which carries with it the imminent or ever-present possibility of harm, injury, and misfortune ... Significantly, many forms of harm are beyond the individual, or even human, control. The process of aging and death, for example, are clear internal, biological processes that show the limitations of human control over the consequences of our embodiment, which is constantly and universally vulnerable". (Fineman 2013, p. 20)

Fineman reminds us not only of the universality of vulnerability, but also of its existential quality. Our human limitations, our very mortality, means that although we may not be feeling vulnerable at any particular moment, we are always thrust in the shadows of our vulnerability because of the simple fact that we will one day no longer exist. Knowledge of this reality can prompt a search for meaning, purpose, and community often satisfied within a religious context (Reker et al. 1987).

It is this very vulnerability that can prime adults for religious experiences. William James in his classic work, The Varieties of Religious Experience, describes the way in which such moments of exposure and failure tune us into a greater state of spiritual neediness: "Let us see ... whether pity, pain, and fear, and the sentiment of human helplessness may not open a profounder view ... " (James 1958, p.118). Because, he writes, human nature is "rooted in failure, is it any wonder that theologians should have held it to be essential, and thought that only through the personal experience of humiliation which it engenders the deeper sense of life's significance is reached?" (James 1958, p. 120). For Rudolph Otto in The Idea of the Holy, the religious moment of holiness involves the self becoming "overpowered" 
by feelings of smallness, "of one's own submergence, of being but 'dust and ashes' and nothingness. And this forms the numinous raw material for the feeling of religious humility" (Otto 1958, p. 20).

Marching to a place of ultimate loss, human vulnerability most often reveals itself in the aging and dying process, in the delicate way transitions are navigated, and in changes that, more often than not, involve loss and grief (Moon 2011; Sands and Tennant 2010). In Necessary Losses, Judith Viorst writes of the harsh price of relinquishing capabilities, willingly or unwillingly:

... we may start to feel that this is a time of always letting go, of one thing after another: Our waistlines. Our vigor. Our sense of adventure. Our playfulness ... We give up hoping to read all the books we once had vowed to read, and to go to all of the places we'd once vowed to visit. We give up hoping we'll save the world from cancer or from war. We even give up hoping that we will succeed in becoming underweight—or immortal. We feel shaken. We feel scared. We do not feel safe. The center's not holding, and things are falling apart. (Viorst 1986, p. 269)

Vulnerability, in this sense, is not always regarded as an opportunity for growth, but as a series of unfortunate events and developments best avoided, as if that were possible. Moments of emotional transition that shake one's assumed foundations can raise difficult questions:

As our past realities start to collapse, we challenge the self definitions that have sustained us, finding that everything seems up for grabs, questioning who we are and what it is we are trying to be, and whether, in this life of ours, the only life we have, our achievements and our goals hold any value. Does our marriage make sense? If our work worth doing? Have we matured-or have we simply sold out? Do our connections with family and friends rest on a loving exchange or on desperate dependencies? How free and how strong do we wish-do we dare-to be? (Viorst 1986, p. 270)

It is often this sense of vulnerability, provoked by a disturbing occurrence or conversation, that catalyzes the last phases of Erik Erikson's eight stages of moral and emotional development. At each of Erikson's stages, a crisis or series of crises must be resolved in order to enter and master the next stage. Failure to make safe passage through any stage will mean that issues will resurface later in life, often presenting themselves as lifelong points of vulnerability.

The three people depicted in this study fall into Erikson's stage 7: Middle adulthood. In between the ages of 40 to 65 , adults may experience a crisis he called generativity versus stagnation. In middle adulthood, adults should be able to see beyond their own needs and give themselves over more fully to caring for others in a state of mutual dependency. Adults will experience stagnation at this stage if they are still self-centered, but will achieve greater contentment from this stage if they nourish others and see the growth and development of others as a primary responsibility. This may be achieved through parenting, work relationships, or caretaking for elderly parents. Some of the self-conscious behaviors of the previous stage have been shed, allowing adults to feel more secure and perhaps less vulnerable or, paradoxically, secure enough to be more vulnerable. Erikson reminds us that, "... emerging human strengths, step for step, are intrinsically beset not only with severe vulnerabilities that perpetually demand our healing insights, but also basic evils which call for the redeeming values of universal belief systems of ideologies." (Erikson 1997, pp. 90-91).

Contrast these views of vulnerability as weakness and susceptibility with the capacity for vulnerability as a positive, relational emotion as popularized by social work researcher, Brene Brown, in a series of books and a TED talk entitled "The Power of Vulnerability" that has had, to date, close to 40 million views. In her book, Daring Greatly: How the Courage to Be Vulnerable Transforms the Way We Live, Love, Parent and Lead, she wrote:

Vulnerability is not weakness, and the uncertainty, risk, and emotional exposure we face every day are not optional. Our only choice is a question of engagement. Our willingness to own and engage with our vulnerability determines the depth of our courage and the clarity 
of our purpose; the level to which we protect ourselves from being vulnerable is a measure of our fear and disconnection. (Brown 2015, p. 2)

To travel through Erikson's stages and to achieve the positive benefits of connection and self-understanding described by Brown's insights on vulnerability requires settings in which experiences can be shared and processed. The adult classroom is, in its most ideal sense, a desirable setting to take part in such exploration. Aryeh Ben-David believes that the challenge of authenticity in education is extremely difficult, "With whom can we ever be fully open, honest, and sincere? With whom can we let down our guard, making ourselves genuinely vulnerable?" (Ben David 2016, p. 8). Not all adult learners or their teachers, however, are consciously attuned to their own vulnerabilities and the challenges and possibilities that such potential exposure offers, especially within the arena of religious instruction. This paper seeks to understand the role that vulnerability played and continues to play in catalyzing religious growth through the experience of Jewish learning in the lives of three adult learners. Palmer observes that, "... teaching is a daily exercise in vulnerability" (Palmer 1998). It seems that learning, for many adults, can also be an act of vulnerability.

\section{Methods}

Qualitative methods were used to gather data about the way three Jewish adult learners engage emotionally with Torah study: Is vulnerability an emotion that surfaces as either a motivator to study or as a result of study and how, more broadly, do respondents conceive of it in shaping their respective religious identities? The present study, conducted in the spring and summer of 2018, consisted of five stages: Sampling, building instrumentation, interviewing, following-up, and analyzing data. The first stage consisted of a selection process to identify adult Jewish learners who had been studying for a period of several years, thus demonstrating a solid commitment to learning, rather than an idiosyncratic interest in a particular subject or instructor. Given the early stage of this work on vulnerability, I wanted to enhance the generalizability of my findings by gathering input from a range of respondents in terms of demographics, age, gender, and religious commitment.

To identify the subjects for this study, I initially reached out to several rabbis across North America of synagogues with strong adult education programs. I also contacted veteran Jewish adult educators in programs taking place in Jewish Community Centers and other organizational settings. Some of the educators I contacted taught in programs, like the Florence Melton School of Adult Education or the Wexner Heritage program. I indicated that I was researching vulnerability in Jewish adult learning and was interested in conducting in-depth interviews with learners "who have taken Jewish study seriously over a long period of time" and were willing to reflect on their experiences. I did not specify age; the pool of contacts I received were between the ages of 50 and 70 years. I narrowed the contacts to six individuals of those suggested. Out of the six people I asked to participate, only three, Audrey, Richard, and Geraldine, were willing to undergo a multi-stage interview process. In my initial contact, I requested two hours of time to answer a survey and to participate in a follow-up phone or in-person interview. I asked respondents not to focus on or to evaluate specific programs or teachers, but to mine aspects of the learning community and their own personal experiences.

It was also important that these learners represent a mix of denominations. To that end, Audrey identifies with the Renewal Movement. Richard describes himself as progressive Modern Orthodox. Geraldine is active in her Conservative synagogue. None was so strongly aligned with a denominational movement that they would not seek study opportunities outside their respective movements.

The second stage consisted of building two instruments: A survey (Appendix A) and a semi-structured open-ended interview. The guided research questions were designed primarily to understand respondents' emotional relationship to Jewish text study grounded in Heilman's notion of lernen, the Yiddish for Torah study that is "closer to a ritual than to intellectual activity" (Heilman 1983, p. 246). This type of learning focuses on content and also one's connection with God, with heritage, community and religious growth; "comprehension is hoped for ... but it is not the sine qua non of lernen ... " (Heilman 1983, p. 246). Given the exploratory nature of this work, questions 
were designed to allow respondents to reflect on what brought them to the Jewish adult education space and what they sought from it. To assess this, I was interested in the specific religious needs, emotional events, or intellectual realizations that may have brought them to the adult classroom, if any. Could each respondent identify a transformative moment as an adult learner that resulted in a change of thinking, feeling, or behavior? Were they seeking out the study of particular topics or teachers with whom they felt they could expose more personal aspects of themselves or privileged content knowledge? Was Torah study a means to access self-growth or a way to build knowledge and mastery or both? Within the emotional range that study may engage, I was interested specifically in how and if vulnerability played a role in shaping the learning experience.

The third stage consisted of "inductive analysis", qualitative coding to understand the survey results "through an analyst's interactions with the data" (Patton 2002, p. 453) before conducting interviews. As Patton notes, one of the challenges of qualitative analysis is to find "ways to creatively synthesize [sic] and present findings" (Patton 2002, p. 58); thus, I tried to identify central themes within each survey response and then patterns across the surveys. Although each respondent was identified with a denomination, each was more interested in accessing texts and traditions in a meaningful and substantive way, wherever that led them. All three demonstrated an ongoing commitment to text study, despite busy work lives and family commitments. The learning community created by adult students was significant for each, and each reflected on the importance of the teacher, even though the questions highlighted other aspects of the Torah study experience to minimize the role of the educator and focus, instead, on the inner life of the learner.

Following the data analysis of the surveys, I conducted hour long semi-structured interviews by phone in the spring of 2018 with each of the three respondents, followed by E-mail correspondence during the late spring and summer of 2018 for additional clarification. This fourth stage was followed by an additional survey (Appendix B) in the fall of 2018 with possible E-mail or phone interview follow-up questions to study with greater depth the relationship of vulnerability as it pertains to each respondent's understanding of religiosity, a connection that was not made explicit in the first round of questions. At this stage, the phone interviews ranged in duration from a half hour to an hour. In this second interview, I tried to understand if the respondents regarded their learning as an expression of religiosity, if they felt that learning subjects other than Judaism-like literature-could equally satisfy their emotional learning needs, and if they could describe what they regarded as the connection between vulnerability and religiosity.

The final stage consisted of data analysis, using verbatim notes and field correspondence, to see where responses colluded and where they diverged, particularly in their basic understanding of the nature of vulnerability and its connection to their Jewish lives.

As qualitative research, this study has several limitations. The interview data has not been triangulated with any other sources to strengthen its findings. It also does not focus on the educational organizations that offer Torah study for adults, the curricula they utilize, or the educators they employ. It also represents a very small sample, privileging in-depth analysis of participant narratives, to begin further inquiry. Future research with a larger pool of participants is necessary to determine the role that emotions and, specifically, that vulnerability plays in the religious lives of adults who engage in Torah study. Knowing if feelings of vulnerability induce greater participation or serve as a desideratum of study or not can make a difference in the recruitment, selection of material, choice of educators, orientation of educators, construction of lessons, and the quality of the learning experience.

\section{Vulnerability as Ignorance}

Audrey began what she calls her "serious interest in Jewish education" about a decade ago. She describes her current commitment to Jewish learning as part of her "religious practice and observance" (E-mail correspondence, 17 October 2018). Audrey does not make "a distinction between 'religious' and 'spiritual' and used the verb 'ingesting' to describe her relationship to sacred texts whether she is "in the sanctuary or in a classroom." 
"Concentration or attention" is for Audrey "a religious act" (E-mail correspondence, 17 October 2018). Dirkx describes the relationship of learning to religiosity for adult learners, like Audrey, as a gateway to spiritual development: "I consider the act of learning to be an inherently spiritual act, at least in potential. It borders on the sacred, flirts with it, invites in the sacred, if we allow it" (Dirkx et al. 2006, p. 130). Jewish texts, according to the research of Guzman-Carmeli and Rubin, are even used in mystical Jewish academies of learning as "tools of power and holiness" to "assist the supplicants in coping with their personal tribulations", specifically read as healing mantras (Guzman-Carmeli and Rubin 2014, pp. 222-23). Audrey has defined her learning as an inherently spiritual act; she can also recall a specific moment of vulnerability that catalyzed what has become a regular part of her life:

I recall having breakfast with a business colleague who was very active in his church's weekly Bible study class. When he began to quote from the Hebrew Bible, I realized I didn't know these verses at all and felt motivated to do something about it. I knew I was missing something. In part this was how it began. I was also asked to serve as the Religious Practices Chairperson at my synagogue and felt quite insecure about what I was doing in this role. My children were older, and there was this growing desire in me to learn more about "my" Judaism. Thus, the journey began. (In conversation, 23 May 2019)

Audrey is 58 and from the mid-West. She has been living in the suburbs of a major cosmopolitan city for 25 years. She has identical twin brothers. One is a rabbi. The other converted to Catholicism. His son is studying to be a Catholic priest. Audrey's sister also converted out of Judaism for marriage. Audrey laughed as she quipped, "Someone described my family as very faithful." Yet despite the seeking nature of her family, Audrey's Jewish development was, in her words, arrested at 14 when her formal, "lack-luster" Jewish education ended. When she met the colleague above for lunch, she reports being both "mortified" by how little she knew and subsequently inspired to learn more. There was something rich he had that she wanted; she also wanted to converse with him using the same religious frames of reference. "I wanted to cure my insecurity, not play into it." For Audrey, vulnerability is insecurity, an uncomfortable sense of not knowing that pushed her to know:

I ... see vulnerability as not being sufficiently competent in my religion to be able to fully participate or appreciate the experience. I think the more we can offer adults the opportunity to learn and study their Judaism in a meaningful, non-judgmental way-taught by excellent teachers-the more Jewish adults, with wide-ranging backgrounds, can contribute and be nourished by our beautiful religion. I know this is true because it has happened for me. (E-mail correspondence, 17 October 2018)

Audrey needed knowledge to participate in conversations that mattered to her and to feel a greater sense of belonging within her current religious community. Her search expresses two of King's nine dimensions used to measure religiosity: "Commitment to Intellectual Search Despite Doubt" and “Openness to Religious Growth” (King 1967, pp. 181-82).

What began as a combination of insecurity and curiosity for Audrey soon evolved into a meaningful and regular commitment to Jewish learning. Audrey had a goal: "To become comfortably literate with history, Bible, liturgy, texts and philosophy—a tall order I know." Much of this desire to study emerged out of her relationship with specific rabbis and instructors; she was looking for "excellent programs and outstanding teachers." Audrey's life is full and busy. "I don't have time to spend learning with a mediocre teacher." Audrey enjoys multi-part programs and has studied in multi-year programs, executive seminars in Israel, and travel/study opportunities in other countries exploring Jewish history. Audrey regards herself as a spiritual person rather than a religious person because she identifies the language of religiosity with strict Jewish observance rather than a way of walking in the world. Holdcraft in "What is Religiosity?" admits that religiosity is "a complex concept and difficult to define" (Holdcraft 2006, p. 89). Words used as synonyms to religiosity, like holiness, devotion, orthodoxy, 
and faith, Holdcraft points out, highlight the "uncertainty and imprecise nature" of language. Learning, for the adults interviewed in this paper, is a manifestation of religiosity broadly defined within the five elements that Glock and Stark identified: The experiential, ritualistic, ideological, intellectual, and consequential (Glock and Stark 1965). Audrey was seeking an intellectual experience of Judaism, but that alone would not satisfy her learning needs. Her study both reinforced and deepened her synagogue involvement, catalyzed ritual observance in her home, and ideologically informed her work. Fukuyama's four dimensions of religiosity—cognitive, cultic, creedal, and devotional—remind us that a person may consider herself religious without engaging in every dimension (Fukuyama 1960). Audrey regards Jewish learning as an expression of cognition and devotion, but not necessarily related to a personal creed or specific worship practices, although this may, on occasion, be the case.

Audrey does not seek out, nor would she attend, a class "advertised as emotional", but she does acknowledge an emotional dimension to her studies: "There have been key people who have offered this world to me and to others, and I have greedily eaten it up. There're a million things that adults can do with their lives and the time is short, but why would I choose to do something that wasn't intellectually, spiritually and emotionally and physically exciting? It's like a drug that I want." She is drawn to non-judgmental settings for study. She wants to dip her "foot in the proverbial Red Sea" and prefers study that offers her a universe of history or ideas that are totally new to her, like Hebrew poetry, Medieval Spanish history, and polemics. "For me, I open myself up to the intellectual aspects." Although Audrey runs a Jewish non-profit organization, her deepest moments of study are surprisingly not around the study of social justice issues. In fact, she describes such Jewish classes as "annoying." She cannot isolate a topic that moves her, but there are moments when Audrey has insight into her life and her work as a result of adult study, and such moments crystalize and confirm important feelings for her: "Wow, this is why I am doing what I'm doing. A calling in both directions. I'm not sure why some classes get me there and some don't ... Let me learn real text study, and if it so moves me to take action, so be it."

Despite her strong intellectual bent or because of it, Audrey has moments during study-rare, powerful, and inexplicable to her-when she finds herself profoundly emotional:

I was studying some Hebrew poetry and broke down and cried in that class. I can't explain why I cried ... it just hit me in such a profound way. Another teacher, who taught some obscure piece on the Amida [the Eighteen Benedictions prayer] really moved me. I went up to him to tell him how much I appreciated the class, and I started to cry. I was moved beyond belief ... It's like a personal revelation in my own little seat. I've had this happen many times ... I never had this experience in law school. (In conversation, 23 May 2019)

In reflecting on what happened then and in other emotional study moments, Audrey seems moved by an almost aesthetic sense of the beauty of what she is learning: "Material that was previously unfamiliar to me all of a sudden becomes alive, and in a few instances brought me to tears because of the depth and quality of the presentation." Study can evoke for Audrey emotions ranging from "love, exhilaration, joy and thrill" to "sadness and challenge." When asked about the role that vulnerability plays in her own experience of adult Jewish learning, she remarked that "new learning can be particularly emotional." She saw this when she moved to the other side of the desk and began teaching in her synagogue. She observed many of her own initial insecurities in those who were coming to the adult classroom for the first time:

One adult learner in the class where I am assisting said she felt "ashamed" that she couldn't keep up with the subject matter. Other people tell me how insecure they feel when they walk into a sanctuary and don't know anything. For some there is a lot of emotional baggage attached to pursuing Judaic learning as an adult. Some students have a mixed relationship with their Judaism for a laundry list of reasons. It is key to provide comfortable, non-judgmental spaces to pursue greater Judaic literacy. 
She tries to project her learning needs on those she imagines were like an earlier version of herself; she wants to be sensitive to their vulnerability in the room. Thinking of her own vulnerability, Audrey recalls another specific moment later in her journey that inspired more adult learning:

Seven years ago, my father had a stroke right after our family was all together for Pesach [Passover] that left him in a coma for seven weeks. He died shortly after Shavuot, after our family made the decision to end his life support. It was a life-changing series of events for which I was desperately seeking answers. With support of dear friends from my synagogue community, I found direction and a Jewish framework to accept and understand how to deal with my father's sudden death. I think this event was a catalyst to spur me on to even greater learning that had already slowly started a bit earlier.

This incremental shift in Audrey is not unusual. "I think I study now to both honor my father and to engage in a true love of all that Jewish learning provides me with including new places and people to encounter along the way." The desire to study as an adult may be heightened after a disjunctive experience, like the birth of a child, retirement, or the death of a parent. Adults experiencing these transitions may seek out Judaism's wisdom and its lessons for modern life as a way to manage the discomfort of transitions:

When Jewish adults have disruptive or "disorienting" experiences that challenge previously held worldviews (such as the death of their parents, the intermarriage of children, encounters with anti-Semitism, divorce, or relocation to a new community), they sometimes wonder if Judaism can help them to "understand" their situation in new ways. When these adults embark on new meaning-making, new learning can transform their view of themselves as Jews. (Tickton Schuster 2003, p. 115)

In their curiosity and discomfort, Jewish adult learners bring to their learning a readiness to reflect upon, and conceivably change, their spiritual trajectories, as will be suggested later in the literature on transformative learning, using and considering study as a way of shifting personal reality, much the way religion functions for many of those who engage it and study it. In addition, many adults discover through the study of sacred texts the relevance of Judaism to their own experience and also encounter questions that they perceive as having religious significance (Grant et al. 2012, p. 15).

... As Jewish adults mature and grapple with pressing questions and ambiguities, they discover paradoxes in their thinking about Judaism and their lives as Jews ... When Jewish adults are grappling with questions of meaning, they find it beneficial to engage in learning and discourse with other learners. (Tickton Schuster 2003, p. 115)

Over time, Audrey became less interested in knowing as a reason for Torah learning, the initial impetus for her learning, and more concerned with personal growth and connection: The connection to God, family, work, community, and her own innermost values. Study helped her make sense of her world.

\section{Vulnerability as Shame and Embarrassment}

The desire to make sense of experience as an animus for study was also true for Richard. Richard's commitment to study reflects Heilman's sense of the "religion of lernen" (Yiddish for learning in its deepest sense). While it is, at heart, an engaging intellectual activity, study for Richard is also an expression of religious obligation: A mitzva. The person engaged in lernen "does so because he feels a duty to do so has been laid upon him by some superior force" (Heilman 1983, p. 245), in addition to satisfying innate curiosity. The lerner tries "to utilize the constructions of the sacred texts and holy rabbis as a framework for his own thinking" (Heilman, p. 242).

Richard, who is 60, grew up in a Conservative home. His mother provided private tutoring in addition to Richard's congregational schooling. He describes himself as "a typical Jewish kid." 
His parents kept a kosher home, but ate non-kosher out. They had Kiddush and Friday night dinner, but that was the extent of Sabbath rituals. In seventh grade, Richard went to Camp Ramah and struggled with the inconsistencies he experienced in his Jewish life and his denomination. He vowed to be more consistent and to learn more. Richard went to public school and Hebrew school. His aunt encouraged his burgeoning Jewish interests and agreed to pay for any religious books he read. His mother was staunchly opposed. She grew up Orthodox and felt religion was restrictive and controlling, "which it probably was," Richard quipped. He is not sure whether his early study was an act of rebellion or a genuine nurturing of the soul. Whatever inspired it, Richard engaged in serious self-study. As an adult, he says, "It hasn't changed all that much: my learning has almost always been a combination of self-study, classes, and mentoring." He feels most vulnerable in a havruta setting, however: "In some ways chevrutah is more vulnerable since I like learning with people smarter than me so feel I need to say something interesting enough to keep them from leaving me." Vulnerability as understood here is a personal state of smallness or lack of worthiness.

Richard bemoaned that he never had the benefit of formal Jewish day school education, a gap year to study as each of his children had, or Ulpan to work on his Hebrew in a structured way. He sometimes struggles with Hebrew texts and does not read or translate quickly, but has created a rich discipline around learning. Like Audrey, for Richard vulnerability is largely associated with ignorance. "Vulnerability to me means a willingness to ask the 'dumb' question or risk putting forward a 'dumb' answer. I am pretty fearless on both counts since I figure I won't learn much if I don't speak up." With prompting, Richard later explained what he considered a dumb question or answer. He recalled a moment when he asked a question in the class of a well-known rabbi and educator, who shot back: "Nothing is ever clear." Richard shared that this was not one of this instructor's "shining moments." Richard was embarrassed in front of the class (E-mail correspondence, 7 June 2018). Richard speaks regularly in a sermon capacity in a minyan (prayer quorum) in his synagogue and used to provide a brief window for congregational havruta study, but stopped because, "several people complained it would mean risking saying something dumb or embarrassing" to another congregant. He understood that people were happier to be passive learners than risk being perceived by their co-religionists as "non-knowers." Someone even sent Richard an insulting E-mail about his efforts to create an atmosphere of study, suggesting that he was "a failure."

Richard began his Jewish adult education studies before he was an adult: "I've been an adult student outside the formal Jewish educational system since high school. Even when attending my Synagogue Sunday school I wanted more learning." Unlike Audrey and Geraldine, Richard's learning has tended to be one-on-one rather than in more formal classroom settings or retreats. "Much of my learning has been tutorials with rabbis or scholars, plus a Shabbat afternoon Talmud study group with neighbors all of whom had day school educations (I like to learn with people who know more than me)" (E-mail correspondence, 19 May 2018). Having said that, Richard confesses to be irritated by those who know less than him and "personsplain" in the classroom, talking too much about themselves. "The better teachers," Richard notices, "usually rephrase your question to something smarter if they think the way you asked it was dumb (or they ask clarifying questions)."

Richard does regularly attend classes at his synagogue and in his community, yet the learning that has had the most impact on him has been in these smaller settings. In recent years, his learning has shifted somewhat. Richard has followed his children. He and his wife sent his children to Jewish day schools from K-12, and they have continued to study in intensive Jewish settings in Israel and New York. Richard studies in the summer in Israel in a well-known center for Jewish learning and has also spent winter and spring breaks studying away from home. He enhances his study through podcasts and havruta-style paired study. He studies Daf Yomi, a page of Talmud a day, by himself, but is aided by a small group of friends with whom he blogs about the daily Talmud learning. Once a week, on Shabbat, the group gets together to review their learning for the week. "I learn on my own out of convenience. I'm not a night person so I don't want to fall asleep when I study." Richard struggled to identify a transformative moment of learning. For him, study has always been incremental and 
constant. If anything, it did not come in the form of a class, but when he began to give divrei Torah in sermon form in his own synagogue. This was empowering for him as he staked his own claim to delivering ideas he had studied with others, putting texts together in creative new ways. His children are a source of learning and inspiration, and he shares his love of study with them, turning to them for legal questions.

Richard is a committed adult learner. Study informs his daily life. He does not believe he can achieve the same satisfaction by studying non-sacred texts; "studying Jewish texts is a completely different discipline than studying any other form of literature. In text study there is a history, philosophy, generations of commentary and sacredness that is all rolled up (scrolled up) for us to study together" (E-mail correspondence, 15 October 2018). He claims that he has "yet to find a piece of literature that offers the same experience" (E-mail correspondence, 15 October 2018).

Yet, in one sense, Richard is grappling with the tensions of knowing a lot and being perceived by others and himself as not knowing enough: "I think I know a lot. If I know a lot about a topic, without being arrogant, I don't want to hear what others have to say. So I prefer small group study or one-on-one. I want to learn with people on the same level. I've formed a lot of small communities around study." For Richard, vulnerability is not about spiritual or emotional exposure. Like Audrey, it's about ignorance. Unlike Audrey, however, Richard has not entirely grown out of these feelings, despite years and years of self-study and classes. For example, when he asks his children to elucidate some aspect of text study, it makes him feel vulnerable: "I certainly make myself vulnerable, and of course nowadays when learning with them I am often learning from them since they know so much more than I." Other moments of vulnerability also touch on what Richard missed out on in his childhood. As a member of an Orthodox synagogue, it is not hard to believe that everyone knows more, even if it is not true. One of his proudest transformative Jewish moments, while not about learning, was about taking a public role in synagogue as a gabai, a volunteer sexton. This role requires facility and frequency with names and the Hebrew language. Richard stepped up:

I was terrible at it, not remembering names, not being smooth with the procedures ... I made myself extremely vulnerable to my kids, going over all but the most confidential matters with them as we planned the aliyot [Torah blessing] for the week and then executing on the plan. Elliot [his son], in particular, stood next to me during davening: correcting me, pointing out which people were which.

This public role has parallels to Audrey's moments of anxiety, demonstrating what she knows in front of others because the perceived expectation of knowledge and competence.

Richard relied on his children, much the way a child would rely upon a parent, to induct him in the intricacies of an enhanced public role in synagogue. Lest this led to his children being embarrassed, Richard has found the opposite happened: "I find it interesting that all three kids have been active gabbaim and minyan leaders wherever they go, but they are far less active in other Jewish organizations (despite Richard's very active involvement in Jewish nonprofits). None of this was deliberate parenting, simply desperation to get my gabbai function right." Making himself vulnerable in front of his synagogue and his children enabled him to grow and model for his family what it means to struggle and gain proficiency.

Richard is not trying to access the emotional in his learning as much as what he calls, "combining the intellectual fun of learning Jewish texts with the recognition that they are meant to make you a better person." He is deeply disturbed, in particular, by behaviors committed by people who are purportedly religious since he views a goal of Jewish commitment and learning as character improvement. Richard later elaborated on this as an obstacle for him in his use of the term "spiritual" when "those who claim today to be most spiritual are often committing terrible crimes in God's name" (E-mail correspondence, 15 October 2018).

Richard describes his religious affiliation as fluid right now. A member of a Modern Orthodox synagogue, during his year of Kaddish, he found himself davening in both a local yeshiva and in egalitarian minyanim and anywhere in between where he could fulfill his responsibility. 
My desire to study transcends the movement. I'm trying to figure out the meaning of life and how Judaism solves that. I've gone from book to book and for the past 60 years, I still haven't found the book that explains it all. I've not been all that well-read outside of Judaism. If there is validity to religion, then Judaism is about as good as it gets. I've never been super curious about what is the Buddhist response or the Christian response. None of it impressed me as far as intellectual content.

Some of this tension is resolved in Richard's community commitments. Despite being touched by certain books and texts, Richard's desire to study comes, in large part, because it is a normative expression of Jewish life and a mitzva as an observant person. He studies not to access his heart, but because that is what Jews do, certainly the Jews in his community. For Richard, being vulnerable may be the opposite of being religious, when vulnerability is equated with the shame of not being able to perform communal rituals and religiosity is equated with the performative aspects of Judaism

I'm not someone who cries when I learn. I'm sympathetic to people who study and feel emotional about their learning or their lives. I have not felt this myself. I don't know that I feel God's presence-lots of bad people say they are in God's presence-so the emotional piece is not a driver. I've tried.

And yet, when pressed, Richard did connect his learning to something numinous, " ... surely the point of Torah Lishmah (learning for its own sake) is to feel that somehow you are getting closer to understanding what God wants from us in this life, and maybe a bit of an understanding as to what God is" (E-mail correspondence, 15 October 2018). Although Richard believes that messages in literature are "easier to handle than from Tanach (Hebrew Bible) where the moral of so many of our Biblical stories are ambiguous," he does believe that Jewish learning, unlike literature, deals with "God and mitzvot (commandments)," even if indirectly at times (E-mail correspondence, 15 October 2018).

Richard has trouble relating to vulnerability as a religious concept: "I read a lot about how God wants the broken heart, broken person, vulnerable, but I'm not good at that. If I'm suffering or dealing with someone else's suffering I tend just to get mad at God even if at some level I know that's not right I'm more about let's serve God in gratitude" (E-mail correspondence, 15 October 2018). He believes that the fear component he associates with vulnerability can even be morally obstructive, "the purpose of God giving us courage and taking away our fear is so we have the courage to do the right thing, to take initiative to do the right thing."

Richard's spirituality is largely connected to the intergenerational nature of study. Ironically, his mother, an early opponent of Richard's religious evolution, asked him a few years before she died to study with him. She wanted to know what it was that Richard so valued in this endeavor. She felt that she had missed out. Richard's response reflected the way that he has always viewed learning as the connective tissue among family and community:

Why don't we figure out how to do some learning together? We invited grandchildren siblings, and it was a Sunday morning conference all. There were fifteen people on our list. We studied by phone every Sunday - we'd get about five. After my mother died, my father wanted us to continue. Then when he passed away, I wanted to continue.

For Richard, the Torah texts he studies often have a lot to say about self-improvement, about "opening up myself to do more." His regular learning does not create transformative moments per se, but a lifetime of closeness that text study catalyzes that strengthens community and family:

I'm like a drip on a rock... Learning with my kids is very special. My kids are living positive Jewish lives and I like to think that I did all this learning with my kids all these years and they see me learning all these years and maybe that has helped them live the Jewish lives they're living. (E-mail correspondence, 24 May 2018) 
Richard is aware of what he missed as a child in terms of his learning. It is this vulnerable place of not knowing that seems to push him forward as an adult learner. " ... in a way I have probably been forever catching up on Jewish education, and still trying to figure out the meaning of life."

\section{Vulnerability as an End Goal of Study}

For Audrey and Richard, vulnerability as ignorance or shame initiated the desire to learn to fill in the gaps and, in some ways, continues to motivate each to study more. For Geraldine, however, vulnerability is not the inspiration to study but the desired outcome of study, a religious worldview that can only be achieved through a state of deep humility that is an expression of the human condition. Her commitment is closer to what Boyarin terms "reliving the collective acceptance of the Torah at Mount Sinai" (Boyarin 1989, p. 214). Geraldine personalizes her study continuously as a means of spiritual self-understanding, following Boyarin's explanation of interpretation as a "dynamic tool enabling mediation between the realities of everyday circumstance and culture, and the impossible demands of imitatio dei ... and the desire to identify one's unique individuality with the essence of Judaism" (Boyarin 1989, p. 214).

Geraldine began her Jewish adult study with a different goal; she wanted to study in order to make a critical life decision: "My Jewish adult education began when I was studying to see if I could become a Jew by choice. I was dating a Jew seriously. He didn't ask it of me. I asked it of myself. All those lessons were okay but not really moving" (In conversation, 29 May 2018). Once, when Geraldine was dating her now husband seriously, he told her that they could not go out to dinner. It was Yom Kippur, and he wanted to go to synagogue. She offered to go with him.

It was like going off the deep end. Sitting in the back of the shul, I wanted to be in, but I didn't know how. I was so self-conscious. Can I open the ark? Now when I see people being uncomfortable, I offer to open the ark with them. I wanted to be part of the spiritual davening community. I wanted to learn how to pray. I felt like once I figured it out, I would have a pathway in. I was so jealous of people who knew what to do.

Like Richard, Geraldine felt vulnerable and exposed because she did not know what to say and do while everyone else around her seemed familiar with synagogue choreography. She can now recognize this embarrassment in others who are new to these intimidating spiritual spaces. Unfortunately, despite a strong desire to learn and fit in, Geraldine's early foray into study was not successful. She found herself unable to connect personally with the texts. Because she had the expectation that Jewish text study would move her emotionally, she wanted to feel something that she could not yet access, even as she saw others who were able to connect in ways both meaningful and nurturing. Bielo, in his ethnography of evangelical Christian study groups, terms the expectations that guide individuals and groups in their reading of specific texts their "textual ideology" and posits that, reading performs important cultural work. It is a place to inherit conceptions from a shared social and theological history and is a moment to take ownership of those conceptions in ways that make sense for readers' own social scenes (Bielo 2009, pp. 51-52). Geraldine was at the precipice of this ownership, but not yet there. Something was missing.

Geraldine, nevertheless, persisted and had a breakthrough moment on a trip to Israel. She insisted on going alone and not with her Jewish boyfriend. This had to be her decision, owned in her own way.

Before I could say yes to joining the Jewish people, I felt I had to go to Israel by myself. That was my big going away-it was like a retreat without calling it that. It was a spiritual journey ... Two memories stick out. I was on a bus and was watching soldiers hitch-hiking and asked my seatmate if it was safe, and she said, "They're all our children." That's when I realized what Am Israel [the nation of Israel] meant. It meant being part of a large Jewish family. (In conversation, 29 May 2018) 
Her second memory was of visiting one of her boyfriend's relatives who had personal Holocaust connections and realizing what this historical inheritance meant to her. This trip transformed her. Life felt complicated, but was getting clearer. Her boyfriend did not ask anything of her.

It was not an issue for him it was an issue for me. It was a mix of emotions and hard to parse out. I believe that for a family to stick together, we have to pray together. Prayer to me is connecting with God, given our constraints. Here is my spouse, a descendant of Holocaust survivors. He has a very strong cultural rooting, and I said, "How is this going to work? How do we root ourselves spiritually?". (In conversation, 29 May 2018)

Geraldine is 48 and was born in the Philippines in a religiously Catholic home. She enjoyed a world-class education in the United States and lives on the East Coast with her family. In thinking about her own childhood and the spiritual lessons she learned, she felt it was important to raise a family with a shared spiritual commitment. "I was a Catholic, and if there's anything my mom imparted to me, it's that a family should pray together. I took that with me." Her parents found her decision difficult, mostly because they cared about Geraldine and wanted to make sure she knew what she was doing. Marriage was a big enough step. Changing one's faith added another dimension of challenge.

In these early days, her attempt to study did not work for her. "I didn't find my groove; I wasn't sure what I was looking for and didn't find the right teachers. Which is hard." She wanted desperately to connect on a heart and head level, to "connect in an authentically spiritual way." Many of the teachers Geraldine met along her path were more concerned about passing on information about Judaism rather than making deeper connections for her. Rather than seeking textual understanding, Geraldine was interested in "textual application," in the way that Bielo identifies it with the "individual, intimate concerns" of the learner (Bielo 2011, p. 239). There was, in her words, "too much suspension of disbelief in the other religions" with which Geraldine was familiar. She felt this to be true for her Catholic upbringing and appreciated the greater intellectual rigor she was increasingly finding in Judaism.

The best parts of study really happened after I was already Jewish. My real journey began because I had to dive deeper into the meaning of things. The best studies involved developing new insights about myself, my relationship with God, and with others through a spiritual and Jewish lens. Today, I study because I want to feel more connected to the Source. I want to be reminded of where I belong in the Universe and what that sense of belonging means-how it manifests in my everyday life. (E-mail correspondence, 19 May 2018)

Religion became Geraldine's way of addressing life's existential questions; study was one avenue in which to do so. In this process of self-discovery, of becoming both Jewish and seeing herself as an adult learner, Geraldine began to realize critical aspects of herself that were always there, but lay dormant. Like Audrey, she sees herself as a lifelong spiritual seeker; a label she only applied when she made the decision to become Jewish.

I felt free because I was rooted to an ancient tradition. I felt free because I was supported by a loving community. And I felt free because Judaism requires questioning and struggling to learn with heart, mind, and soul. It's a beautiful process and one that I am incredibly grateful to be engaged in and to have discovered. [E-mail correspondence, 19 May 2018]

Text learning for Geraldine came in bits and pieces: "What I look for in a teacher is someone who not only understands the text but can make me feel that it relates to my life, and that's why I love studying now because Torah is a living text that expands your mind...My learning came hand in hand with my doing and the more I engaged in the Jewish community, the more I wanted to learn because I needed to understand what I was doing and you can't access that without the text." For Geraldine, immersive experiences have proven more transformative and important to her Jewish life than the regular, weekly classes that a learner, like Audrey, enjoys. Regular study commitments are harder for 
her given her intensely demanding job and family life: "Learning happens best for me when I am on some kind of spiritual retreat because I am open, focused, and not distracted by anything else around me." She has gone on missions to Israel and other countries and been on retreats to Canyon Ranch and Kripalu. She can also achieve this when "somewhere beautiful and serene or close to nature is preferred to reflect one's higher self." Her rabbi would often give her readings that they would later discuss.

This is not to say that I have not had powerful learning sessions when not on retreat, it's just that I seem to be more impacted when I am away. I also know that I have learned something really powerful when I need quiet and space right after an intense session of learning in order to integrate the information into myself. I go into a form of meditation and prayer. I often start to cry to release emotions no matter what they may be (happiness, sadness, confusion, revelation, etc.). I write a lot in my journal. (E-mail correspondence, 19 May 2018)

Unlike Audrey, who sought Jewish literacy through mastery of specific texts and bodies of Jewish literature, Geraldine turns to her adult study as a way to access her inner life, her emotions, to create a space of silence and introspection. Study is a religious act for Geraldine, although she hesitates to use the term, religious, because of what she perceives are negative, exclusionary associations with the word:

"Religious" can be a very heavy word with many connotations and (for better or worse) can evoke feelings of guilt, lack of worthiness, and inability to live up to pious perfection. So if my adult learning involved studying the siddur [prayer book], for instance, or some element of prayer, I guess it could technically be viewed as an extension of prayer and thus a religious act. But I prefer to use to the word "spiritual" to describe my Jewish studies because it is more inclusive, expansive, compassionate, and forgiving, and thus allows for more openness in study which leads to deeper learning. (E-mail correspondence, 23 October 2018)

Geraldine concedes that any great literature, like the study of sacred text, can remind a person of "our shared humanity" and shared a recent experience of reading a poem that made her cry. Yet, she believes that Jewish learning is, for her, ultimately a more moving experience because of the broader framework in which it is situated: "the context for Jewish teaching, which is based on specific stories, values, language, and cultural understandings add greater depth and meaning to my studies" [E-mail correspondence, 23 October 2018].

For Geraldine, her best study sessions alter how she thinks and feels "immediately after the learning." At such times, when a class has been particularly moving she feels something powerful occurring within her that is less intellectual and more emotional.

I feel an expansion of my mind and heart. I find myself more open and compassionate. I am more grateful. I feel like I belong. I feel completely enveloped and loved by spirit and G-d. I feel blessed, connected, and happy. I feel fully supported and empowered to fulfill my life's mission on this planet. [E-mail correspondence, May]

Audrey associates vulnerability with insecurity around knowing, a feeling she overcame with time and now recognizes in others, who, like an earlier version of herself, lacked knowledge and competence in aspects of Jewish life. Geraldine's understanding of vulnerability is more existential, a condition of life that her adult Jewish study helps her tap into rather than avoid: "I don't think true learning can occur without vulnerability, which is an authentic openness to new ideas and feelings, whatever they may be. It requires open-hearted listening. It requires trust." Because this kind of open-hearted listening and trust is difficult to achieve, Geraldine believes that identifying a good teacher is very important; the teacher "sets the tone for the entire experience. The more vulnerability the teaching requires, the more important the tone that the teacher sets." This does not happen in every classroom, but it happens sometimes: "A good teacher can help guide the student to open her heart, to realize her true nature and self, and to recognize the most beautiful, empowered person that God 
created her to be." Geraldine was seeking learning environments where her relationship to God could be safely and lovingly explored, and she could be her authentic, open self.

For Geraldine, one of the gifts of good teaching is the creation of sacred space before study. Religiosity is the creation of such spaces. She appreciates when a teacher establishes a circle of safety. "I think that this is why rituals are so important in our lives. Rituals provide sacred spaces for us to elevate by allowing for the safe expression of emotions." This takes time and intention. "Depending on the kind of study involved, some kind of preparation might be required to allow for readiness and openness. Again, some kind of ritual might be helpful ... It signals that we are in a different space and that we are now going to be doing and being something special." (E-mail correspondence, May)

Reflecting on a recent moment of vulnerability took Geraldine back to that early experience of being in a synagogue on Yom Kippur, a time when she had no idea what was going on. The service was conducted in Hebrew, yet she was haunted by the music, in particular the Hebrew melody for "Aveinu Malkaneu" (Our Father, Our King), a piece of liturgy she could not have named at the time she first heard it. Almost 20 years later, on another Yom Kippur, the rabbi asked her to hold the Torah on Kol Nidrei. When they reached the prayer of Aveini Malkenu, Geraldine started to cry:

I told myself, "Please don't drop the Torah." I was getting emotional about the journey. I wasn't holding the Torah. I was holding myself up ... Almost twenty years. And it just hit me. I was so grateful and surrounded by so many people I love. You go through life cycles together-it's what it's all about. My advice is not to be afraid. The only thing that keeps someone from being open and vulnerable is fear. Maybe it's fear of being exposed. Maybe it's fear of coming off as not real. It's all an illusion because what's inside your vulnerable self is your true self, and when you open yourself, you allow other people to open themselves, and it's the greatest gift.

The vulnerability Geraldine describes, of feeling overwhelmed by emotions and exposed in a very public space, did not happen in an adult classroom; it happened in a synagogue. For Geraldine, unlike Audrey and Richard, study, ritual, and liturgy seemed to be less discrete aspects of spiritual life; they are woven, even blended together, and mutually affirming. The connection between religiosity and vulnerability can appear seamless to Geraldine:

Being vulnerable means being open, and being open requires humility to something greater than oneself. In the same way, a person who is religious has devoted himself or herself to a higher purpose, to come ever closer to the person who was created in G-d's image. So being vulnerable is being open to learning and growing, as the religious person does every time he or she listens to and prays to G-d. [E-mail correspondence, 23 October 2018]

\section{Making Meaning}

For Geraldine, Torah study helped her create a new arch to her life, one that allowed her to look back and see a non-linear path that began to make sense. Richard's path and patterns of study were more linear and disciplined, but, he, too, tied the "forever catching up" sentiment in his adult learning to figuring out the meaning of life. The philosopher, Todd May, in his book A Significant Life, argues that if human life is to have meaning, a personal narrative trajectory has to make sense: "Our lives gain meaningfulness when we are engaged in a life trajectory that expresses one or more narrative values. When we are absorbed by the unfolding of our life, when it makes sense to continue to do what we do, when we endorse our projects: that is half of it" (May 2015, p. 135). This requires the capacity to put the pieces that may be disjointed or nonsensical in any life into a semblance of coherence through the process of self-justification, a process that can take place in the adult classroom. There remains, according to May, another half: "When that unfolding occurs by way of subtlety or integrity or intellectual curiosity or intensity of any other positive value that would capture its temporal character, then we have the other half of it. To the extent that these two halves meet, we have a meaningful life" (May 2015, p. 139). 
Jewish adults enter or re-enter the Jewish classroom for a variety of reasons. Some adults, like Audrey and Richard, are seeking information, discrete skills, or a means of problem-solving. Others, like Geraldine, come to the adult classroom seeking God and life wisdom, community, a connection to ritual and heritage, or a way to bring greater every day meaning to their lives (Tickton Schuster and Grant 2006). This is the kind of meaning that May describes.

The learning process, therefore, is rarely neutral for many Jewish adults (Reimer 1990, p. 23). It is often driven by an insecurity around their heritage or previous negative experiences that can make them feel paradoxically vulnerable and empowered: The ignorance Audrey felt at that breakfast inspired her to study, the insecurities Richard feels in relation to performative aspects of Judaism, around his children, or congregants "smarter" than he is, or the isolation Geraldine experienced in the back of a synagogue that made her want to sit in the front. They, like so many adult learners, approach Jewish study beset by inadequacy, often manifest by not participating in group conversations or assuming that other learners in the room know more (Tickton Schuster 2005). They may be afraid that the teacher might discover their ignorance, as Richard's teacher had in that moment he described. This sentiment is sometimes expressed aloud when asking a question: "I'm sure everyone else knows the answer to this" or "I know this is a stupid question, but ... " or "I'm embarrassed to admit this."

Betsy Dolgin-Katz and Roberta Goodman in The Adult Jewish Education Handbook sensitize us to the value that Jewish adults place in feeling both competent and confident in their Jewish lives and how adult education can help in that process.

Learning can provide the skills and knowledge that augment an adult's feelings of confidence as a Jew. Adults used to feeling competent in their work, relationships, special interests, volunteer roles, and family life want likewise to be confident in performing rituals in the home or synagogue, in prayer, in answering questions of non-Jewish friends or colleagues, and in grappling with difficult questions about life and death, good and evil, and purpose and direction. They want to be able to find resources and to use the tools that can help them access answers. Unfamiliar often with the vocabulary of Jewish life, and even less adept at understanding Hebrew or translating Hebrew texts, they still want to know enough to feel included in the Jewish venture. (Goodman and Katz 2004, pp. xi-xii)

If indeed Jewish adult learners seek study experiences that can provide a setting for exploring deep and personal questions stimulated by teacher, text, and other learners, then adult educators, aware of these pedagogic needs, should provide both content, context, and learning modalities so these needs can be addressed. Geraldine sought out teachers who created a circle of safety before exposing her deepest feelings about what she was learning and who she was becoming as a Jew by choice. She sought out Jewish experiences that nurtured her soul, in the manner of Dirkx's meaning: "Constructivist, active, and experiential forms of teaching and learning, marked by high levels of uncertainty, ambiguity, contradiction, and paradox, invite expressions of soul" (Dirkx 1997, p. 82). The philosopher, L.A. Paul, argues in Transformative Experience that we know so little about ourselves and the way we work, "... in many ways, large and small, as we live our lives, we find ourselves confronted with a brute fact about how little we can know about our futures, just when it is most important to us that we do not know. For many big life choices, we only learn what we need to know after we've done it, and we chance ourselves in the process of doing it" (Paul 2014, p. 10). It is in this confrontation with ambiguity that feelings of vulnerability can catalyze change: "When a person has a new and different kind of experience, a kind of experience that teaches her something she could not have learned without having that kind of experience, she has an epistemic transformation. Her knowledge of what something is like, and thus her subjective point of view, changes" (Paul 2014, p. 10). 


\section{Religiosity, Adult Jewish Study, and Transformative Learning}

We have an extensive body of literature on transformative learning, what Elias calls "the expansion of consciousness through the transformation of basic worldview and specific capacities of the self" (Elias 1997, p. 3). We know less, however, about how these deep and personal changes take place and how to inspire them in the Jewish adult classroom. Using the observations of these three Jewish adult learners-Audrey, Richard, and Geraldine-against the backdrop of research in the arena of transformative learning, psychology, and philosophy, perhaps transformative learning for Jewish adults is most likely to occur in classrooms where learners can expose their vulnerabilities, however defined, in warm, safe, and challenging educational settings. Indeed, many Jewish adults may come to the classroom in search of both content and an environment that can help them navigate through text study difficulties in their personal and professional lives not addressed elsewhere. John Dirkx explains that, "Many adults participating in formal learning experiences find themselves 'in between' phases of development, where the meaning structures of the old phase seem 'frayed' or no longer relevant to their life experiences" (Dirkx 1998, p. 5). However, unless these adults match their seeking with finding, their questions and needs will not be satisfactorily addressed through study; adult learning will not provide these learners with the context in which to wrestle with what brought them to the classroom in the first place. Over time, Audrey, Geraldine, and Richard understood more about what they wanted from the adult classroom, in terms of teacher, learning community, and setting and were able to find study environments that accommodated their needs and relinquished those that did not meet their needs. They were not motivated to study by extrinsic concerns, such as status or membership, within a conventional religious structure. They experienced joy and connection in the act and tried to embody what they learned: "The extrinsically motivated person uses his religion, whereas the intrinsically motivated person lives his religion" (Allport and Ross 1967, p. 434).

Environments that honor personal exposure and provide facilitative learning within a nurturing community allow adults to confront and process transitions through the medium of text study and conversation. Not only can vulnerability deepen the integration of content in such settings, it can catalyze profound personal growth by creating readiness for change against what Israel Scheffler calls "unruly inner turbulence" (Scheffler 1991, p. 3). Placing the Jewish adult learner within the larger context of central tenants in transformative learning can help illustrate an important tool and means to tame the chaos within.

Transformative learning theory was developed in the late 1970s by Jack Mezirow. Mezirow contends that transformative learning is a "rational process of learning" that involves "a metacognitive application of critical thinking that transforms an acquired frame of reference-a mind-set or worldview or orienting assumptions and expectations involving values, beliefs, and concepts—by assessing its epistemic assumptions" (Dirkx et al. 2006, p. 124). For Mezirow, this reflective process occurs largely outside the realm of awareness, involving emotions, intuitions, contemplation, and imagination. Within conscious awareness, the learner understands that there may be an alternative way to view an issue or problem. Through study, the adult student challenges personal assumptions and beliefs and establishes and validates new ways of thinking and being. This process also involves managing the anxiety attendant with this change of reference. Finally, the adult learner feels sufficiently empowered by this shift in perspective to take action based on new, validated beliefs (Dirkx et al. 2006, p. 124). For Mezirow, this process of transforming beliefs or "habits of mind" involves 10 phases (Mezirow 2000) and is usually catalyzed by a disorienting dilemma (Cranton 1994) that provokes self-assessment and eventuates in a change of belief and then behavior. When Audrey lost her father, for example, she described the ripple effects of loss: "It was a life-changing series of events for which I was desperately seeking answers. With support of dear friends from my synagogue community, I found direction and a Jewish framework to accept and understand how to deal with my father's sudden death." Brookfield adds that merely contemplating one's thoughts or observing them does not constitute transformative learning. This occurs in adult students only when there is a significant shift in thought or behavior (Brookfield 2000). Audrey describes that her father's death did lead to an 
important shift in behavior: "I think this event was a catalyst to spur me on to even greater learning that had already slowly started a bit earlier."

Mezirow's approach can be overly rational and not sufficiently attuned to the emotional aspects of transformation (Taylor 1998, pp. 33-34; Taylor 2001; Dirkx 1998; Boyd and Myers 1988). In Geraldine's case, learning is highly emotional, and the capacity to express the emotions that make her feel exposed and vulnerable is what she actually seeks in a study experience. When she was becoming Jewish, she needed information, a "how-to" guide, yet what reached her most even at that early stage were experiences that helped her connect to God, family, and humanity. Dirkx, emphasizes the subjectivity of the adult's inner life; shifts in perspective require awareness of one's feelings and emotions in the learning process to "make-meaning" of experience (Dirkx 1998). As Geraldine got to know herself as a learner, she was able to seek out experiences and learning environments that helped her make meaning.

Some may find it challenging to marry Judaism's strong intellectual tradition with the kind of emotions both Audrey and Geraldine discussed, particularly in communities where text study is regarded as a legal obligation and a normative practice. Dirkx, however, challenges common assumptions about emotions that have stymied a proper discussion of their role in learning: " ... emotion has for many years been regarded as separate from both our cognitive and bodily processes and an anathema to reason and knowing" (Dirkx 1998, p. 14). Elsewhere, he writes that we have yet to comprehend fully the role that emotions play in learning because of a predisposition to question the worth of emotions generally: "Emotion is not something that simply invades our experiences of teaching and learning, an alien force trying to mess up our best-laid plans and intentions, a manifestation of our weak character or ability to control our emotions" (Dirkx and Clark 2008, pp. 89-90). In this limited view, even "expressions of so-called positive emotions, such as joy or elation, are often regarded as pleasant interruptions of an otherwise sober environment" (Dirkx 2008, p. 11; Dirkx and Spurgin 1992). When Audrey describes being moved to tears by her learning without the ability to explain why, she does not seem embarrassed, but deeply moved, as if these feelings represent a place of awe and achievement in her study.

As early as 1954, Joseph Schwab wrote a seminal article on the role of emotions within learning and the narrowness of what often constitutes or is regarded as intellectual life. In "Eros and Education: A Discussion of One Aspect of Discussion," he contends that, "No greater injury has been done the intellectual than by some of his proponents," specifically with regard to suspicions about the inner life: The emotions, where life and school are isolated from each other (Schwab 1954, p. 52). "Training of the intellect must take place ('must' in the sense of 'unavoidably') in a milieu of feelings and must express itself in actions, neither symbolic or actual” (Schwab 1954, p. 53).

Eros, the energy of wanting, is as much the energy source in the pursuit of truth as it is in the motion toward pleasure, friendship, fame or power. Any means or method of education taps this energy source to the extent that the method of education taps this energy source to the extent that the method is at all effective, and the best means of education will be one which taps it most effectively. (Schwab 1954, p. 54)

Dirkx contends that emotions are themselves powerful teachers: “ ... through the expression of affect and emotion in adult learning, we are offered a kind of language for reinterpreting ourselves and the possibility to experience and recreate our sense of selves, our subjectivities, our being in the world" (Dirkx and Clark 2008, p. 90). Others have studied and described the spiritual process inherent in transformative learning, even within professional development in the workplace (Tisdell 2003; Whyte 2002; Merriam et al. 2007; English et al. 2003; Bierema 2008).

Richard, though far less emotional about the role of adult study in his life, regards learning as a way to shape experience that may require making oneself insecure: Studying with people who know more, giving sermons to his highly-educated congregation, taking a public role that requires significant ritual mastery. In the spirit of transformative learning, Richard thinks about the impact of his learning on his life and the life of his family and the way his pursuit of study shapes him, in the way Dirkx 
describes the self as "... active, with a strong sense of agency, acting on and often creating the worlds which it inhabits. It is a reflective, dialogical, expressive, and deeply emotional and spiritual self that constructs and re-constructs itself through experiences of learning" (Dirkx 1998, p. 11). Mezirow also acknowledges the role that transformative learning plays in spiritual development for adults, particularly when it involves reflection on texts: "That relationship is spiritual enough. It carries with it its own ritual, symbolism, imagery, and wonder. Out of this relationship somehow merges meaning of a sort, a meandering wave of sense making that can permeate much of our being" (Dirkx et al. 2006, p. 130).

In looking at a portrait of three Jewish adult learners-Audrey, Geraldine, and Richard-a combination of curiosity, vulnerability, and a desire to connect to others within a Jewish context brought each to the classroom. The desire to know and belong was coupled with a provocative, evocative, and insecure sense of not knowing that motivated each to greater learning and often translated into a full-throated religious experience. Geraldine defined vulnerability in learning as the gift of being able to expose her emotions. Richard defined it as the ability to ask questions that risk exposing ignorance. Audrey, like Richard, regarded vulnerability as ignorance, and, like Geraldine, saw her high points of study as moments of profound connection and emotion. For all three, some of their most powerful moments of study and religious transformation emerged when learning was charged with emotion. In the discomfort zone that was strangely both safe and unsettling, each harnessed personal vulnerability to connect meaningfully to God, to tradition, to others, and to themselves. The vulnerability that started their journeys induced, over time, an even greater desire to study more.

Funding: This research received no external funding.

Conflicts of Interest: The author declares no conflict of interest.

\section{Appendix A Vulnerability in the Jewish Adult Classroom}

(1) Please describe your interest in Jewish adult education, how long you have been studying and what you look for in a class:

(2) Can you identify a transformative moment for you as an adult learner? Please be as specific as possible about subject, setting and any outcomes (change of thinking, feeling or behavior).

(3) As you think about your journey in Jewish adult education, in addition to skill and knowledge acquisition, can you describe emotions that study has evoked for you?

(4) Some researchers are investigating the role of vulnerability in education. What do you think "vulnerability" means and what role does it play in your learning?

(5) What role do the following factors have for you in creating a climate that is safe for the expression of emotions...

The teacher:

Other students:

The setting:

The topic:

Other:

(6) What specific life events, if any, have prompted you to engage in adult learning?

\section{Appendix B}

(1) We tend to use religious in the sense of observance instead of pertaining to the spiritual. With this latter definition, do you feel that your adult learning is a religious act? Please explain your answer.

(2) Could a class in literature, let's say, satisfy your learning needs in the same way that a class in Jewish text does? Please explain. 
(3) You shared moments of vulnerability with me in your learning and Jewish journey. What do you see as the connection between vulnerability and religiosity?

\section{References}

Allport, Gordon W., and J. Michael Ross. 1967. Personal Religious Orientation and Prejudice. Journal of Personality and Social Psychology 5: 432-43. [CrossRef]

Ben David, Aryeh. 2016. Becoming a Soulful Educator: How to Bring Jewish Learning from Our Minds, to Our Hearts, to Our Souls-And into Our Lives. Woodstock: Jewish Lights.

Bielo, James S. 2009. Words upon the Word: An Ethnography of Evangelical Group Bible Study. New York: New York University Press.

Bielo, James S. 2011. 'How Much of This is Promise?' God as Sincere Speaker in Evangelical Bible Reading. Anthropological Quarterly 84: 631-53. [CrossRef]

Bierema, Laura L. 2008. Adult Learning in the Workplace: Emotion Work or Emotion Learning? In Adult Learning and the Emotional Self. San-Francisco: Jossey-Bass, pp. 55-64.

Boyarin, Jonathan. 1989. Voices Around the Text: The Ethnography of Reading at Mesivta Tifereth Jerusalem. Cultural Anthropology 4: 399-421. [CrossRef]

Boyd, Robert D., and Gordon J. Myers. 1988. Transformative Education. International Journal of Lifelong Education 7: 261-84. [CrossRef]

Brookfield, Steven D. 2000. Transformative Learning as Ideology Critique. In Learning as Transformation: Critical Perspectives on a Theory in Progress. Edited by Jack Mezirow. San-Francisco: Jossey-Bass, pp. 125-50.

Brown, Brene. 2015. Daring Greatly: How the Courage to Be Vulnerable Transforms the Way We Live, Love, Parent and Lead. New York: Avery.

Cranton, Patricia. 1994. Understanding and Promoting Transformative Learning. San Francisco: Jossey-Bass.

Dirkx, John M. 1997. Nurturing Soul in Adult Education. New Directions for Adult and Continuing Education 74: 79-88. [CrossRef]

Dirkx, John M. 1998. Transformative Learning Theory in the Practice of Adult Education: An Overview. PAACE Journal of Lifelong Learning 7: 1-14.

Dirkx, John M. 2008. The Meaning and Role of Emotions in Adult Learning. In Adult Learning and the Emotional Self. San Francisco: Jossey-Bass, pp. 7-18.

Dirkx, John M., and M. Carolyn Clark. 2008. The Emotional Self in Adult Learning. In Adult Learning and the Emotional Self. San Francisco: Jossey-Bass, pp. 89-95.

Dirkx, John M., and Michael E. Spurgin. 1992. Implicit Theories of Adult Basic Education Teachers: How They Think about their Students. Adult Basic Education: An Interdisciplinary Journal for Adult Literacy Educators 2: 20-41.

Dirkx, John M., Jack Mezirow, and Patricia Cranton. 2006. Musings and Reflections on the Meaning, Context, and Process of Transformative Learning: A Dialogue between John M. Dirkx and Jack Mezirow. Journal of Transformative Education 4: 123-39. [CrossRef]

Elias, Dean. 1997. It's Time to Change Our Minds: An Introduction to Transformative Learning. ReVision 20: 2-7. English, Leona M., Tara J. Fenwick, and Jim Parsons. 2003. Spirituality of Adult Education and Training. Malabar: Kreiger. Erikson, Erik H. 1997. The Life Cycle Completed. New York: W.W. Norton and Company.

Fineman, Martha Albertson. 2013. Equality, Autonomy and the Vulnerable Subject in Law and Politics. In Vulnerability: Reflections on a New Ethical Foundation for Law and Politics. Edited by Martha Albertson Fineman and Anna Grear. Surrey: Ashgate.

Fukuyama, Yoshio. 1960. The Major Dimensions of Church Membership. Review of Religious Research 2: 154-61. [CrossRef]

Glock, Charles Y., and Rodney Stark. 1965. Religion and Society in Tension. Chicago: Rand McNally.

Goodman, Roberta Louis, and Betsy Dolgin Katz. 2004. The Adult Jewish Education Handbook. Denver: A.R.E. Press.

Grant, Lisa, Diane Tickton Schuster, Meredith Woocher, and Steven M. Cohen. 2012. A Journey of Heart and Mind: Transformative Jewish Learning in Adulthood. New York: Jewish Theological Seminary Press.

Guzman-Carmeli, Shlomo, and Nissan Rubin. 2014. 'Tikkun' (Divine Repair) and Healing in a Kabbalistic Yeshiva: Using Sacred Texts as Healing Devices. Contemporary Jewry 34: 217-41. [CrossRef] 
Heilman, Samuel C. 1983. The People of the Book: Drama, Fellowship, and Religion. Chicago: The University of Chicago Press.

Holdcraft, Barbara. 2006. What is Religiosity? Catholic Education: A Journal of Inquiry and Practice 10: 89-103. [CrossRef]

James, William. 1958. The Varieties of Religious Experience. New York: Penguin Books.

King, Morton. 1967. Measuring the Religious Variable: Nine Proposed Dimensions. Journal for the Scientific Study of Religion 6: 173-85. [CrossRef]

Little, William, Henry Watson Fowler, and Jessie Coulson. 1973. Oxford English Dictionary, 3rd ed. Oxford: Clarendon Press.

Mackenzie, Catriona, Wendy Rogers, and Susan Dodds. 2014. Vulnerability: New Essays in Ethics and Feminist Philosophy. New York: Oxford University Press.

May, Todd. 2015. A Significant Life: Human Meaning in a Silent Universe. Chicago: University of Chicago Press.

Merriam, Sharan B., Rosemary S. Caffarella, and Lisa M. Baumgartner. 2007. Learning in Adulthood: A Comprehensive Guide. San-Francisco: Jossey-Bass.

Mezirow, Jack. 2000. Learning to Think Like and Adult. In Learning as Transformation: Critical Perspectives on a Theory in Progress. San-Francisco: Jossey-Bass.

Moon, Paul J. 2011. Bereaved Elders: Transformative Learning Late in Life. Adult Education Quarterly 61: 22-39. [CrossRef]

Otto, Rudolph. 1958. The Idea of the Holy. London: Oxford University Press.

Palmer, Parker J. 1998. The Courage to Teach: Exploring the Inner Landscape of a Teacher's Life. San Francisco: Jossey-Bass.

Patton, Michael Quinn. 2002. Qualitative Research and Evaluation Method, 3rd ed.Thousand Oaks: Sage Publications. Paul, Laurie Ann. 2014. Transformative Experience. Oxford: Oxford University Press.

Reimer, Joseph. 1990. Toward a Theory of Adult Jewish Education. Pedagogic Reporter 23: 22-24.

Reker, Gary T., Edward J. Peacock, and Paul T. P. Wong. 1987. Meaning and Purpose in Life and Well-being: A Life-span Perspective. Journal of Gerontology 42: 44-49. [CrossRef]

Sacks, Jonathan. 2009. The Koren Siddur. Jerusalem: Koren Publishers.

Sands, Diane, and Mark Tennant. 2010. Transformative Learning in the Context of Suicide Bereavement. Adult Education Quarterly 60: 99-121. [CrossRef]

Scheffler, Israel. 1991. In Praise of Cognitive Emotions. New York: Routledge.

Schwab, Joseph J. 1954. Eros and education: A Discussion of One Aspect of Discussion. The Journal of General Education 8: 55-71.

Taylor, Edward W. 1998. The Theory and Practice of Transformative Learning: A Critical Review. Columbus: ERIC Clearinghouse on Adult, Career, and Vocational Education, The Ohio State University, No. 374.

Taylor, Edward W. 2001. Transformative Learning Theory: A Neurobiological Perspective of the Role of Emotions and Unconscious Ways of Knowing. International Journal of Lifelong Education 20: 218-36. [CrossRef]

Tickton Schuster, Diane. 2003. Jewish Lives, Jewish Learning: Adult Jewish Learning in Theory and Practice. Springfield: Behrman House.

Tickton Schuster, Diane. 2005. Adult Jewish Learners: Entering the Conversation. Journal of Jewish Education 71: 245-47. [CrossRef]

Tickton Schuster, Diane, and Lisa D. Grant. 2006. Adult Jewish Learning: What Do We Know? What Do We Need to Know? Journal of Jewish Education 71: 179-200. [CrossRef]

Tisdell, Elizabeth J. 2003. Exploring Spirituality and Culture in Adult and Higher Education. San-Francisco: Jossey-Bass.

Viorst, Judith. 1986. Necessary Losses: The Loves, Illusions, Dependencies and Impossible Expectations that We All Have to Give Up in Order to Grow. New York: Simon and Schuster.

Whyte, David. 2002. Crossing the Unknown Sea: Work as a Pilgrimage of Identity. New York: Riverhead Books.

(C) 2019 by the author. Licensee MDPI, Basel, Switzerland. This article is an open access article distributed under the terms and conditions of the Creative Commons Attribution (CC BY) license (http://creativecommons.org/licenses/by/4.0/). 